3. Adityan B., Thappa D. Profile of acne vulgaris a hospital-based study from South India : Indian Journal Dermatol Venereol Leprol. 2009. № 75. P. 272-278.

4. Layton A., Zeichner J. Top ten list of clinical perls in the treatment of acne vulgaris : Advances in acne management. 2016. № 2. P. 147-152.

DOI https://doi.org/10.30525/978-9934-588-79-2-2.13

\title{
БІОТЕХНОЛОГІЧНЕ ТЕСТУВАННЯ ЗА ДОПОМОГОЮ НАЙПРОСТІШИХ
}

\author{
Стрілець О. П. \\ доктор фармачевтичних наук, \\ професор кафедри біотехнології \\ Національного фармацевтичного університету \\ Стрельников Л. С. \\ доктор фармачевтичних наук, \\ професор кафедри біотехнологіi \\ Національного фармацевтичного університету \\ м. Харків, Україна
}

В останні роки стала актуальною розробка нових експрес-методів оцінки різних біологічних об'єктів, включаючи продукти харчування, кормові добавки, косметичні засоби, тощо. На даному етапі розвитку науки численні дослідники віддають перевагу інноваціям в області біотестування, інтенсивний розвиток якого почався у 1950-х рр минулого століття, і продовжується зараз. Практика використання найпростіших (Protozoa) в якості тест-організмів нараховує не одне десятиліття [1, с. 49].

Вперше законодавчо біотестування було уведено у радянські часи у другій половині 20-го століття, яке використовувалось для контролю стічних і природних вод.

У теперішній час біотестування затребуване у самих різних областях: біотехнології, медицині, ветеринарії, екотоксикології, фармації, косметології, хімії. Об'єктом біотехнологічного тестування може бути люба продукція рослинного, тваринного, синтетичного і навіть генетично-модифікованого походження [3, с. 28]. 
Оцінку токсичності кормів, продовольчої сировини, фармакологічних препаратів, косметичних засобів, харчових продуктів і інших об'єктів проводять за допомогою інфузорій Tetrahymena pyriformis, Paramecium caudatum, Paramecium putrinum, Paramecium omrelia, Stylonychia mytilus, Colpoda steini i інших. Результати біотестування на Paramecium гарно корелюють із результатами, отриманими у дослідах in vivo на теплокровних тваринах $[4$, с. 33$]$.

За даними Е.Г. Черемних [3, с. 28] інфузорії як тест-організми при біотестуванні володіють такими перевагами:

- найпростіші, як еукаріоти, в одній клітині мають властивості окремого організму, тому можуть бути використані при біотестуванні як інтегральні сенсори не тільки на окремі сполуки, але i на сукупність діючих факторів;

- велика чисельність популяції досягається завдяки високій швидкості поділу і короткого циклу розмноження;

- реакція на токсичні сполуки проявляється за короткий термін часу, завдяки чому можливо проведення експрес-тесту на великій кількості досліджуваних зразків;

- при допомозі найпростіших можлива оцінка токсичності не тільки водорозчинних сполук, але і розчинних в органічних розчинниках;

- завдяки відносно великим розмірам інфузорій можливо проведення експериментів за допомогою простого біологічного мікроскопу.

В Свропейській Конвенції про захист хребетних тварин, що використовуються для наукових експериментів, вказано, що слід максимально обмежувати використання вищих тварин для експериментів, віддаючи перевагу іншим методам досліджень і одночасно створюючи нові методики [2].

Таким чином, в економічній і етичній сферах біотестування має велику перевагу, бо дозволяє скоротити, у тому числі економічні, витрати на утримання і використання лабораторних тварин.

На кафедрі біотехнології Національного фармацевтичного університету протягом останніх років формується новий науковий напрямок, який полягає у проведенні досліджень із використання біотехнологічного тестування як методу біологічного контролю для аналізування нових косметичних засобів, лікарських форм фармацевтичних препаратів, продуктів харчування, сировини, зразків питної води тощо [5, с. 696]. Серед різноманіття біологічних тест-об'єктів було обрано представника найпростіших (Protozoa) - інфузорію туфельку Paramecium caudatum. Першим етапом досліджень було проведення серії експериментів із вивчення поживних середовищ для культиву- 
вання, умов культивування і виділення чистої культури Paramecium caudatum для подальшого використання у біотестуванні. Проведені дослідження показали, що серед проаналізованих і обраних, за даними огляду літератури, поживних середовищ, а саме таких, як: поживне середовище $з$ листя салату, поживне середовище із сінного настою та середовище Лозина-Лозинського найбільш оптимальним виявилось поживне середовище Лозина-Лозинського, яке забезпечує Paramecium caudatum всіма необхідними компонентами для росту та розвитку, повністю відповідає вимогам для культивування і накопичення чистої культури. Проведені попередні дослідження, та отримані експериментальні результати з вивчення протективної дії, антиоксидантних властивостей та можливого токсичного впливу зразків нових косметичних, фармацевтичних засобів, дерматокосметичних фітокомпозицій i різних груп продуктів харчування для оцінки їх якості і безпечності показали можливість і доцільність використання найпростіших, а саме, інфузорії Paramecium caudatum в якості тест-об'єкту. Проведений комплекс досліджень дає можливість зробити висновок, що біотехнологічне тестування за допомогою найпростіших $є$ більш вигідним, i $є$ перспективною альтернативою методам 3 використанням хребетних лабораторних тварин у різних областях науково-дослідницької діяльності.

\section{Література:}

1. Долгов В.А., Лавина С.А., Никитченко Д.В. Оценка и взаимосвязь параметров токсичности различных веществ для инфузорий тетрахимена пириформис и белых крыс. Вестник РУДН. 2014. № 2. С. 49-54.

2. Европейская конвенция о защите позвоночных животных, используемых для экспериментов или в иных научных целях. Страсбург, 18 марта 1986 г.

3. Черемных Е.Г., Симбирева Е.И. Инфузории пробуют пищу. Химия и жизнь. 2009. № 1. С. 28-31.

4. Чеснакова С.М., Чугай Н.В. Биологические методы оценки качества обьектов окружающей среды. Владимир: Изд-во Владим. гос. $y н-m .2008 .92 \mathrm{c}$.

5. Fedorovska M., Polovko N., Strilets O. Optimal concentration selection of active pharmaceutical ingredients in the cream-mask intended for androgenic alopecia treatment according to experimental results on paramecium caudatum biological model. The Pharma Innovation Journal. 2019. № 8(3). P. 696-700. 